\title{
Narrative and the Politics of Identity: Patterns of the Spread and Acceptance of Radicalism and Terrorism in Indonesia
}

\author{
Firdaus Syam ${ }^{1}$, Fachruddin Majeri Mangunjaya ${ }^{2, *}$, Ajeng Rizqi Rahmanillah ${ }^{3}$ \\ and Robi Nurhadi ${ }^{1}$ \\ 1 School of Graduate Studies, Universitas Nasional, Jl. Harsono RM, Ragunan Ps Minggu, Jakarta 12550, \\ Indonesia; firdaus.syam@civitas.unas.ac.id (F.S.); robi.nurhadi@civitas.unas.ac.id (R.N.) \\ 2 Centre for Islamic Studies, UniversitasNasional, Jl. Sawo Manila, Pejaten Ps Minggu, \\ Jakarta 12520, Indonesia \\ 3 International Relation Studies, UniversitasNasional, Jl. Sawo Manila, Pejaten Ps Minggu, Jakarta 12550, \\ Indonesia; ajeng.rizqi.rahmanillah@civitas.unas.ac.id \\ * Correspondence: fmangunjaya@civitas.unas.ac.id
}

Received: 9 April 2020; Accepted: 4 June 2020; Published: 12 June 2020

\begin{abstract}
This study aims to examine Islamic narratives heard at mosques and in study groups in the greater metropolitan area of Jakarta, Indonesia. The article asks if youth and leaders of youth organizations in Jakarta are receptive to radical/terrorist discourse or if they deliberate and weigh what certain narratives mean. Qualitative in-depth interviews were conducted with 24 subjects. These included Rohani Islamic group leaders who hold extracurricular study groups after middle and high school classes, as well as Islamic Mission organizations or Lembaga Da'wah Kampus (LDK-literally translates as Campus Mission Organization; they are some senior students and may invite Islamic scholars or themselves teach Islam and preach to students who are willing to learn Islam specially only at the university as an extracurricular activity; in this article, we translate it as Islamic Mission organization.). which exist on Jakarta's university campuses where radical narratives are discussed. Other organizations and their leaders were also included. Questions posed to members of these organizations by the authors of this article asked if they accepted, rejected, or negotiated certain ideas regarded as radical by the Indonesian government. Respondents were asked if they believed violent acts against non-reform Muslims and non-Muslims were justified. Respondents were also asked if the Indonesian constitution, Pancasila, should continue its secular democratic legal format, or if it should be replaced by sharia law. Ultimately, most informants took more moderate stances, somewhere in between pure secularism and pure radical terrorism. In this way, this study disproves scholars such as Martin van Bruinessen (2013) who claim that Indonesian Islam is becoming more conservative, and others such as Harsono who claim Indonesian Islam is becoming more violent. While violence was condoned by some respondents, this article reveals that a majority of respondents rejected the view that sharia law should prevail. Ultimately most respondents in this study decided a balanced viewpoint was the best. Thus, this article reveals the degree of moderation of most Jakarta residents, and the nuance and depth of consideration that devout individuals give to a range of contemporary ideas as they negotiate their stance on religion, the state, and their local identities.
\end{abstract}

Keywords: youth; organization; radicalism; terrorism; Jakarta 


\section{Introduction}

Indonesia is the most populous Muslim country in the world, home to more than 209 million Muslims, accounting for $87 \%$ of the national population. ${ }^{1}$ Established as a secular nation in 1945 , the Indonesian constitution, known as the Pancasila, states that all monotheistic religions shall be respected. Indeed, the Pancasila is evident in Jakarta society, for all of the various other religions, including Christianity, Hinduism, and Buddhism, can be found in the nation's capital, Jakarta, together with various sects of Islam. ${ }^{2}$

Jakarta is a metropolitan city, the capital of Indonesia, and serves as the center of the Indonesian government. It is also an important business center in Southeast Asia. Because of its strategic and complex function, Jakarta has become a melting pot for various groups from many regions and countries. Jakarta, portrayed graphically, resembles cobwebs amid a haystack. There is a pattern of regularity, which is also evident in the cobwebs. However, Jakarta (or the cobwebs) is often biased because it is in a tangled environment.

As the metropolitan capital of the nation, Jakarta is the center of the secular government, the home to flourishing international businesses, and the home to leadership and headquarters for various, mostly Islamic, religious organizations. The question is: How does this melting pot of secular and religious administrative organizations co-exist in Jakarta when there are also a range of ethnicities and advocates from regional areas of the country? Given that Islamic radicalism and secularism do not always coexist well, how are radical religious ideas and social movements regarded in Jakarta? If one graphically maps the habits of Jakarta's residents, one would see a series of webs piled high, one upon the other, revealing how complex and intertwined interpersonal interactions are in this vast capital city of 10.5 million people ${ }^{3}$. From the aspect of religion and belief, ethnic, culture, economics, and other demographic factors, the people of Jakarta are a miniature representation of Indonesia's heterogeneous diversity.

The questions asked here are how does this complex community deal with so-called radical/terrorist ideas and non-Muslim groups, while also maintaining their secular government's ideals as stipulated in the Indonesian constitution? Much has been written on Islam in Indonesia (Azra 2002; Van Bruinessen 2013; Hefner 2001; Bowen 1993; Harsono 2019; Hefner 2016), although most of the scholarship on conservatism or radical Islamism has concluded that there has been a major turn toward conservatism (Van Bruinessen 2013; Hasan 2007) and violence (Harsono 2019). Several events in Indonesia prompted this scholarly presumption, in particular the bombings of a nightclub in Bali in 2002, a JW Marriot hotel in 2009, and a Starbucks coffee shop in Jakarta in 2016. Such high-profile targets of Westernization in Indonesia, bombed by "radicals," underlined a constant perception that a clear divide exists between those more secularly oriented and those moving more toward radical Islamic anti-Western beliefs.

The question is if scholars are correct in presuming that after 9/11 Indonesians turned toward the conservative Arab influence and away from the West. Has this persisted since the early days after 9/11? Are van Bruinessen and Harsono correct in declaring that violence and conservative Islamic ideas are more accepted in Indonesia than during the Soeharto era? The current effort to analyze potentially radical narratives looks at ways in which such ideas are spread through discursive interactions between Indonesian young people and leaders of their organizations. None of the authors who presumed a radical turn and acceptance of radical terrorism in Indonesia, other than Bowen (1993) and Kolig (2005), have considered how Islamic narratives are perceived by individuals in organizations.

1 https://databoks.katadata.co.id/datapublish/2019/09/25/indonesia-negara-dengan-penduduk-muslim-terbesar-dunia.

2 Acording to National Statistic Agency (BPS) the religious breakdown of the population of Indonesia is: Islam 87.1\%, Protestant 2.9\%, Catholic 1.69\%, Hinduism 0.72, Bhuddism 0.05, and Confusianism 0.13. https://sp2010.bps.go.id/index.php/ site/tabel?tid=321\&wid $=0$.

3 The population of Jakarta in 2019 was 10.5 millon according to Kata Data. https://databoks.katadata.co.id/datapublish/2019/ 09/10/jumlah-penduduk-dki-jakarta-2019-mencapai-105-juta-jiwa. 
There was undoubtedly a backlash in Indonesia to the secular government's move to label a number of suspects as "terrorists." A view was expressed that the government rules put into place after the Bali bombings were unconstitutional, and that the authorities had gone too far and illegally instituted laws against "terrorists."

Another related question is: Do youth in contemporary Jakarta still find radical Islamic ideas acceptable, or is there a move back to the middle, in between extreme secularism and radical Islam?

To understand what is occurring, this article avoids looking at the process of hearing and interpreting narratives instilled with Islamic values as merely a matter of passive acceptance, without forethought or consideration, on the part of young acolytes who hear from respected leaders intent upon reforming Indonesian democracy. Instead, for the purposes of this study, it was assumed, as Bowen did in his book Muslim Discourses (Bowen 1993), that so-called radical ideas can be discussed by members of Islamic groups, and also analyzed, interpreted, and dynamically blended with secular concepts. This discursive process involves interpersonal networks that overlap and intersect in such a way that allows a dynamic flow of ideas and interpretations. As Situmorang (2007) has noted, social movements involve a collection of people, usually in some loosely organized effort to encourage or reject changes in the status quo. In other words, radical groups are not distinguished from moderate groups, as Kolig found in Central Java (Kolig 2005).

\section{What Is Radicalism and What Caused It?}

Conceptually, according to Taher (Azca 2013, p. 24), radicalism is not synonymous with terrorism, and the term radical is derived from the Latin radix, meaning root. Thus, radical thinking is synonymous with thinking down to the roots. In other words, then, radicalism is that which questions the status quo. Radicalism should be seen as a collective political phenomenon and not as a mere individual psychological phenomenon.

Local opinions about radicalism in Indonesia often cite contemporary issues. One, in particular, that appeared in the narratives was the view that the Indonesian secular government had overstepped its role soon after the 2002 Bali bombing when it declared that state police had complete authority to arrest (and perhaps kill or torture) those suspected of terrorism. After the 2002 Bali bombing, and the 2018 Surabaya bombing, the Indonesian congress issued government regulations stating the police had the right to incarcerate or kill any suspected terrorists (Suryadinata 2018). However, this regulation was deemed by many to be a sign the government was taking too much of an authoritative stance against religious and constitutional rights. This was consistent with the view that human rights were violated when nation states such as Indonesia overstepped their boundaries and began to emphasize security over freedom (Benedek 2010; Benedek and Yotopoulos-Marangopoulos 2004).

Some scholars, such as Van Bruinessen (2013), viewed the tensions in the region as a result of 9/11. Conservative Muslims, van Bruinessen argued, believed the turn toward the West, with its consumerism and decadence, was corrupting Indonesian youth. Van Bruinessen (2013) addresses this issue by stating that there is a constant tension in Indonesia between the turn toward Saudi religious movements such as Wahabism and Salafism, and the alternate influence of Westernization. Van Bruinessen also attributes this to the fact that, after 9/11, many Westerners began to characterize all Muslims as terrorists and, as such, pushed many people, including some Indonesians, toward more radical thinking. Another group of scholars view the disenfranchisement of youth and the social inequities they experience as the reason or motivation for their radicalization (Fitriani et al. 2018).

\section{Research Method}

This study, conducted as a form of qualitative research, was aimed at generating data in the form of written or spoken words from people being observed (Moleong 2006). As a case study, this research intended to study in detail particular social units that include an individual, a group, or an institution. The data were collected through interviews, observations, and a study of documents. 
The interviews were conducted with leaders of Islamic rohani (rohis) in high schools, figures of Islamic Mission organizations, mosque youth, youth organizations, religious leaders, preachers, mosque management (takmir), political activists, and cultural leaders in Jakarta.

In this research, descriptive analysis was used to create a systematic, factual, and accurate picture of the facts and nature, and the relationship among them, of the phenomenon investigated. The data obtained were then presented and analyzed using a descriptive technique, which included a series of data reduction and data presentation activities, and a conclusion was developed. The analysis of this study not only provides explanations through descriptive sentences but also attempts to give clarity to the research object (Moleong 2006, p. 36).

\section{Finding and Discussion}

\subsection{Social, Political, and Religious Setting in DKI Jakarta}

According to Jakarta metropolitan government in 2005, the composition of religious followers in the city was as follows: Islam, $84.4 \%$; Protestants, $6.2 \%$; Catholics, 5.7\%; Hindus, $1.2 \%$; and Buddhists, $3.5 \%$. The share of Buddhists also includes those who follow Confucianism. This composition was not significantly different from the religious composition in 1980, which was as follows: Muslims, $84.4 \%$; Protestants, 6.3\%; Catholics, 2.9\%; Hindus and Buddhists, 5.7\%; and non-religious, $0.3 \%$. According to Cribb (2000), in 1971, the adherents of Confucianism in relative terms comprised $1.7 \%$ of the population. However, the 1980 and 2005 censuses do not record religious affiliations other than those of the six religions recognized by the government.

Various places of worship of world religions can be found in Jakarta. Mosques and Mushalas, as houses of worship for Muslims, are scattered throughout Jakarta, and can be found in almost every environment. The biggest mosque is the national mosque, i.e., Masjid Istiqlal, located in Gambir. There are a number of other important mosques, such as Masjid Agung (the Great Mosque) Al-Azhar in Kebayoran Baru, Masjid At-Tin in Taman Mini, and Masjid Sunda Kelapa in Menteng. Christians also have large churches in Jakarta, such as, for Catholics, the Jakarta Cathedral Church, the Church of Santa Theresia in Menteng, and the Church of St. Jacobus in Kelapa Gading. In addition, for Protestants, there is the Immanuel Church, located opposite Gambir Station, the Koinonia Church in Jatinegara, the Jakarta Zion Church in Jakarta Kota, and the Toraja Christian Church in Kelapa Gading, North Jakarta. For Hindus who live in Jakarta and the surrounding areas, there are places of worship, such as the Pura Adhitya Jaya located in Rawamangun, East Jakarta, and the Pura Segara in Cilincing, North Jakarta. The houses of worship for Buddhists are, among others, Vihara Dhammacakka Jaya in Sunter, Vihara Theravada Buddha Sasana in Kelapa Gading, and Vihara Silaparamitha in Cipinang Jaya. The places of worship for the Confucians in Jakarta are the Temple of Jin Yin Tek. In addition, a synagogue is used by Jewish foreign workers.

Jakarta is a melting pot of all social groups fragmented in terms of religion, ethnicity (tribes), culture, economics, and other factors. This fragmentation of Jakarta's people into these different social groups has created a dynamic that frequently has given rise to social radicalism in the fight over economic resources. In addition, political radicalism has also emerged as a way to seize political and economic power.

\subsection{Narratives on Islam, the State, and Politics}

The respondents involved in this study generally showed a moderate stance against the political system in Indonesia. The narratives do not radically criticize or reject the existing system. In general, informants opined that the political system is a tool to achieve the goal of providing benefits to the citizens. This view implies that whatever the system does is not important; its most important function is to provide for the well-being of human beings. However, the respondents criticized the existing system for not yet being an ideal one. They considered that the political influence in the management of the country is too large; therefore, the country's resources and energy are severely drained by 
political activities. Consequently, some crucial issues that would benefit the citizens and the country, i.e., economics, education, health, and others, are subject to neglect. An Islamic Mission Organizations University of Indonesia (UI) committee member stated the following:

"I saw that there were too many parties in Indonesia, so that our energy is drained for political activities. As a result, other aspects, such as economic issues, have become less overcome. It is not a problem to follow the existing system, for it is basically a tool to achieve the goal, i.e., the realization of benefit."

In addition, the respondents apparently had moderate attitudes towards the democratic system. Most respondents agreed or did not reject the democratic system, and others conditionally agreed with it. The respondents did not reject democracy but evaluated that there are weaknesses in its implementation. Democracy in Indonesia has not been complemented by the level of maturity and the level of education of the citizens. Therefore, the majority of respondents rate the democracy in Indonesia as having gone too far.

Didi Setiadi, the Chairman of Komite Nasional Pemuda Indonedia (KNPI) Kepulauan Seribu, claims that the political system of Indonesia is highly democratic but there are weaknesses in its implementation. However, he considered that Pancasila was in accordance with Islam and supports the concept of Negara Kesatuan Republic Indonesia (NKRI). He says the following 4 :

"The political system in Indonesia, I think, is quite democratic. Even, it is too democratic to the point that it creates a dilemma for government. For now, I disagree that our society should be given very broad democratic freedom. This is a boomerang for Islam. Yes, to some extent, there are some that are conformable, and some are not so. Pancasila, in Islam, is more universal. (Is Pancasila compatible with Islam?) Yes. NKRI, in my opinion, is "a fixed price" for us to defend, and we should not let anyone mess it up."

A similar sentiment was echoed by Ahmad Zaenudin, Islamic Youth Movement (GPI) Jakarta Brigade Commander. He stated ${ }^{5}$ :

"When it comes to democracy, it does not change that much. If you look at political parties, the system is still a monarchy. Thus, the current system does not support it. I would not fix it by radical ways. Let us criticize it from the outside through real actions. Fundamentally, Pancasila and NKRI do not contradict to Islamic teaching since the Prophet Muhammad never talked about the state and Islam is indeed rahmatan lil 'alamiin. Mercy for the universe."

Some respondents felt that, as a form of a democratic system implementation, the process of generally and directly electing leaders is not entirely good. In the democratic system, everyone has the right to pick and choose leaders, but a majority of voters may not have a sufficient understanding and the wisdom to determine leaders. As a result, regardless of the individual's quality, the elected leaders can be anyone and may possibly be elected based on popularity. Moreover, this election process may provide the possibility of misuse by certain interest groups.

Some respondents stated that democracy is not fully in accordance with Islam. However, with respect to Indonesia's current condition, they did not reject the system. There are two considerations the respondents proposed in this regard. First, the system's implementation should be adapted to specific situations and conditions. Second, as long as the system is still considered appropriate or closely in accordance with Islamic values, democracy is regarded as an acceptable tool or instrument that aims to establish benefits for people. In other words, democracy as a tool can be anything and does not have to formally carry the label of Islam. More importantly, its goal is achieved through its

Didi Setiadi. 2014. September 15, 2014.

Zainudin. 2014. “Dialog Pencegahan Terorisme” FKPT-Tokoh Agama Hotel Sofyan Betawi. Saturday, November 15, 2014. 
benefit to humanity. The chairman of the Youth Mosque Organization (Remaja Masjid) in Northern Jakarta stated the following:

"It (democracy) did not exist in the Prophet Muhammad's era, but if democracy is defined as deliberation, it means just talking about methods (of democracy as a method in making decisions or choosing a leader). So, it is legitimate (allowed), if beneficial. Depending on the conditions (if today the democratic system is possible to be applied, it does not matter, as long as it can be beneficial). Implementation of any system is largely determined by its leaders. The disadvantage (of the democratic system implementation) is that all people with different capacities have the same vote (voting with the same power at the time of the election). The ways conducted by the prophet are difficult to apply today, as people's thoughts are very diverse."

A similar narrative was provided by the Chairman of the Islamic Mission Organization Universitas Negeri Jakarta (UNJ). He asserted that democracy basically does not come from Islamic teachings. However, for Indonesia's current situation and the political system existing today, democracy is not considered a problem. This is because the democratic system is viewed as still including positive values that are not contradictory with Islamic values, although there are some parts of the implementation that are considered to be less than ideal. Even though it is not fully in accordance with Islam, it is considered the closest to the values of Islam.

The respondents' narratives on Pancasila and the concept of Republic Indonesia (NKRI) were generally very positive. All responses declared that Pancasila and NKRI are something good and instruments that benefit the lives of society and the nation. The respondents mostly agreed on this view of these two concepts. Respondents embraced these attitudes because the respondents claimed that the Pancasila and the concept of NKRI are not inconsistent with Islam. A respondent from Islamic Defeated Front (FPI), for example, said that "Pancasila has been well received and is not contrary to Islam." A similar response was also delivered by the Religious Harmony Forum-Forum Kerukunan Umat Beragama (FKUB), who said "the majority people no longer see Pancasila as an issue."

A number of respondents specifically questioned Pancasila's implementation. They felt that, as a concept or ideology, Pancasila is good, but they continued to face the problem of practicing the values of Pancasila in their daily lives. This issue was revealed by three groups of respondents, i.e., the Majelis Ulama Indonesia (MUI), Confederation Forum of Betawi Association-Bamus Betawi, and Partai Kebangkitan Bangsa (PKB) party figures. A MUI respondent stated the following: "Pancasila is not an issue, yet its practice is questionable." PKB figures expressed, "the very issue of Pancasila is that it has not yet been put into practice."

In line with the above narratives, a representative of the Islamic Mission organization of UI believes that Pancasila is not an issue when applied as a basis or system of values in life as long as Pancasila is not juxtaposed with the Qur'an. Pancasila was positioned as an instrument, interpretation, or declaration to strengthen the implementation of noble values. He stated the following:

“Not a problem (with Pancasila), as long as Pancasila is not aligned with the Qur'an. As such, Pancasila should be positioned as a formal declaration to strengthen the values, not as the primary basis."

A similar comment was expressed by the leader of the Islamic Mission organization Lembaga Da'wah Kampus-LDK from UNJ (Universitas Negeri Jakarta). He felt that there was no problem with Pancasila because Pancasila is not in opposition to Islamic values, although it is not labeled as part of Islam. He claimed:

"(Pancasila) as a value system is fine. This country is the achievement of the struggle of our predecessors, who were mostly Muslims. See the previous formulation of Pancasila (there were some words written "to implement sharia law for Muslims"). (I saw that) it (Pancasila) did not contradict Islamic values, although it does not use any Islamic terminology. If its application is not in accordance with the values of Islam, it must be denied." 
The respondents' narratives on NKRI are as positive as their narratives on the concept of Pancasila. All respondents from various categories even agree and accept the concept of NKRI. They reasoned that NKRI is an instrument to strengthen the unity and sovereignty of the country. The respondents of the LDK said the following:

"I accept (agree). Do not let this country become fragmented! There are souls of nationalities (which bind a unity as citizens). However, these conditions do not erode the concept of harmony of Muslims among nations."

A similar narrative was expressed by another LDK respondent, who stated the following: "No problem (with NKRI). It is a good thing to unite people in the country. Its implementation must be in conformity with Islamic values covering the guarantee in exercising rights to practicing religious teachings."

For the activists of the ethnic and cultural based-organizations in Jakarta, such as Kembang Latar, Pancasila and the 1945 Constitution is "the fixed price" that cannot be negotiable. Their proximity to national figures and youth organizations, such as Pemuda Pancasila, is evidence of this. In fact, in our conversation, an activist of Latar Kembang stated that his mass organization has an emblem bearing a stallion and surrounded with rice and cotton. Rice and cotton are symbols of social justice for all people-this is obviously an influence of Pancasila. Therefore, when asked about their view of radicalism and terrorism, two activists of Kembang Latar stated unequivocally that there was no place for both ideologies in their mass organization. While smiling, one of them stated the following:

"We do not want to interfere, if not disturbed. Our slogan is indeed obvious: a thousand friends are still not enough, an enemy is too many ... once upon a time, one of our people successfully managed to capture terrorists in Pamulang, and now he has a position that is quite strategic there (Police) and this was enough to prove that our attitude is in line with the most..."

Similarly, with respect to Forum Betawi Rempug (FBR), although they are frequently reported for their acts of violence, their political attitudes towards race and religion do not point out any understanding of the narratives of radicalism and terrorism. In FBR's culture and strategy, violence, which can be quite vicious, exists. Nonetheless, their culture and strategy seem far from Islamism. When found guilty, the individuals' motives for their violent acts are more prone to be ones other than religion and politics. Moreover, the FBR's current Chairman, Haji Lutfi Hakim, is an alumnus of Pesantren and graduated from the Faculty of Da'wa Universitas Islam Negeri (UIN) Syarif Hidayatullah, Jakarta. Some activists from Ciputat even testified that Lutfi Hakim was a campus activist and was active in the Student Forum Ciputat (FORMACI), a study group that is widely known for its progressive ideas. After the death of El-Hajj Fudholi Muhir, who was his relative, he was inaugurated as the next Chairman of FBR. One of the FBR activists in South Jakarta said that he was interested in joining FBR because this mass organization would give him the opportunity of mobility that he wanted while remaining within the realm of ethnicity, nationality, and Islam.

\subsection{Narratives on Islamic Sharia}

In the respondents' narratives, there was a wide diversity of opinion between those who agreed and those who disagreed on the need for the enforcement of sharia law in Indonesia. Some respondents did not actually say that they agreed or not, but they were pessimistic about the possibility of sharia law enforcement. This attitude would appear from respondents, such as those in the Front Pembela Islam (FPI), Majelis Ulama Indonesia (MUI), Bamus Betawi, and Partai Kebangkitan Bangsa (PKB). The FPI figures stated that, for the moment, it was not easy to impose sharia law in Indonesia. The same statement was also expressed by MUI. PKB's board has even explicitly declared that it is not necessary to impose sharia law. Bamus Betawi and FKUB had the same view on this issue. They said that the imposition of sharia law will cause divisions. The figures of PKS commented that although Pancasila 
has been deemed good and sufficient to serve as a foundational value because it has been widely accepted by society, how these values can be implemented in life remains unclear.

The groups that agreed and provided support for the implementation of sharia emerged from the group of Rohis respondents in high school, youth organizations, and campus $d a^{\prime} w a h$ agencies, as well as a number of prominent figures of the mosque youth. Two Rohis respondents from senior high school said that sharia law has to be applied. All groups of Rohis supported having Indonesia as an Islamic state, while all clusters of youth community organization stated the opposite. This polarization means many things. Maturity and the abilities to reason and think logically could be factors that may be important variables that influence different views. Other factors are related to experiences and engagements in society and in the country. Regardless of the reasons for their views, the Rohis groups seem more prone to accept the spread of radicalization or extreme Islamism.

Although most of these respondents agree or encourage the application of sharia law, they have different views on its application. Information indicates that the respondents who agree with sharia law do not reflect radical ideas in their views on the means and the mode of its application. Respondents from Kesatuan Aksi Mahasiswa Muslim Indonesia (KAMMI), for instance, stated that sharia actually has been widely applied in a number of rules of law, although it has not been formally labeled as sharia. A similar view was also stated by a member of the board of LDK from UI. He felt that sharia is good and true and that it should be applied. However, he argued that the application of sharia law should not use a formal label, i.e., sharia. The important thing, he said, was that the substantial basis of Islamic values is implemented in the legal process. Regardless of the name of the system and its origin, if the contents are in accordance with Islamic values, it is actually the implementation of sharia. Therefore, some informants say that sharia implementation does not need a formal channel in the political system in Indonesia, such as political parties, elections, or parliament. They place more emphasis on propaganda ( $\left(a^{\prime} w a h\right)$ activities (movement) as a great media mechanism to build up the rule of shari'ah. One commented as follows:

"I am very confident in the sharia because it comes from God. It should be applied. (Its application) should not always be labeled as sharia, but its substance has to be Islamic. (This is considerably realistic) for now. That means that it does not need to say 'this is the shariah.' The importance is its substance (containing Islamic values)."

The respondent further stated:

"The sharia system is the best. The application of the sharia system cannot be done instantly. The substance is more important. The process of implementing the sharia system is done through the missionary ( $\left.d a^{\prime} w a h\right)$ movement. Do not put forward the symbols of Islam! The importance is its substance (Islamic). The important thing is good content, which includes anything that comes from the West or from Christianity, because it is basically Islamic."

In line with the views on sharia, in different ways of expression, the majority of respondents also tended to show a less positive attitude towards the establishment of an Islamic State. The respondents stated that the application of sharia is the important thing, not the establishment of the Islamic State. The majority of the people already received Pancasila. The issue with Pancasila is how to practice it. According to the respondents, the issue of establishing the Islamic State could break up Indonesia, resulting in the disintegration of the country. The respondents stated that they just needed to practice Pancasila well. One of the PKB figures explicitly stated that they did not need an Islamic state. Only respondents from the Rohis of the senior high schools expressed a view that Indonesia must turn into an Islamic State.

Respondents representing religious activists on campus (i.e., the Islamic Mission organization-LDK) reflected a more realistic, rational, and flexible view of the Islamic State. Their view is that sharia is a system which is regarded as the best and most ideal. Nevertheless, in their view, the concept of the Islamic State should not always be mentioned with respect to a formal label. In reference to 
the concept of the Islamic State, they emphasize its substance, which means that, although the name may not appear as Islamic State, the concept that is implemented and managed by the state should in many respects reflect Islamic values. This concept concerns changes in culture, outlook, and behavior. For that reason, it takes time and a long struggle to make it happen. Hence, directional changes of these conditions should use the existing rules or tools in order to avoid the resultant collisions and the radicalism that might be counterproductive. A respondent of the LDK from UI stated the following:

"There is no need to formally label an Islamic State, but the substance should be Islamic. The substance exceeds the form. The realization of (these expectations) requires a long struggle and must follow the process, rules, or existing tools."

The respondents from the UNJ also reflected the same narratives on the Islamic State. A respondent claimed the following:

"Indonesia has not yet been able to do that at this time, as our society is not conducive to that. For now, we cannot formally become an Islamic State. We are not ready. This has to be continuously defended. There is something more significant, i.e., the application of Islamic values (in various aspects of life)."

\subsection{Narratives on Violence}

Kustana (2017) observed the emergence of global terrorism, and noted its potential to be spread to Southeast Asian nations. He questioned how Indonesia could face internal challenges to conduct counter-terrorism of the false jihad with multi-track diplomacy, primarily with counter-terrorism programs of the police and the National Agency for Combating Terrorism. Kustana said: "In the perspective of defense strategy, the issue of terrorism brings several implications. The condition of Indonesian community with low educational levels and low economic income becomes a target for terrorist actors to expand the network by developing and recruiting new members. The threat of Islamic terrorism is categorized as a national security threat."

The Indonesian Government, through its security apparatus, must still make efforts to apprehend other terrorists, to undertake preventive efforts to prevent Islamic fundamentalist beliefs from developing, and to increase education and encourage a wider understanding of Islam (Kustana 2017).

Zakiyah (2016) said that the chronicle of terrorism in Indonesia dated back to the nation's colonial past. It started with the revivalist movement during the colonial era; Masyumi and Negara Islam Indonesia-Tentara Islam Indonesia (NII/TII) contributed to the formation of the roots of radicalism in the post-colonial era. Historically, the Darul Islam/Tentara Islam Indonesia (DI/TII) Rebellion led by Kartosuwirjo was against both the Dutch and the idea of an Indonesian secular state. Moreover, the main aim of the resistance was the establishment of an Islamic State and implementation of sharia law.

However, this organization constituted an embryo of contemporary Islamic radical groups, such as Majelis Mujahidin Indonesia (MMI) and Jamaah Islamiah (JI), due to the similarity of their ideology and their membership, family, and kinship interconnections.

Based on several reports, the terrorists in the majority of bomb attacks across Indonesia are associated with JI. Primary and secondary evidence shows that the perpetrators confessed that they were members of JI. The targets of the attacks varied and included bars, churches, mosques, hotels, embassies, and police offices. Each of these targets had a meaning, such as a symbol of the West, symbol of the "toghut" state, and symbol of the capitalist. The doctrine of jihad provided ideological support to engage in the terror action. This can be seen from the involvement of martyrs in suicide bombings as they were ready to die for the sake of religion (Zakiyah 2016).

This research shows that narratives on violent behavior are quite diverse. However, there is a relatively consistent pattern in the narrative of most of the respondents. Most respondents conveyed a critical, realistic, and rational narrative with respect to violent behavior committed by a group of people against another group. Not all acts of violence were considered blameworthy and not all acts of 
violence were justified. The respondents tended to critically analyze every act of violence. Behavior involving the raiding of a church was judged as something that cannot be justified, as it violates an individual's rights to practice their religion. This attitude was reflected by the majority of respondents and was clearly indicative of the moderate attitude of the majority of the respondents towards religious differences. A member of the LDK Board of UI, for example, stated: "I do not agree with raiding places of worship (church) because it violates their rights." The same statement was also delivered by LDK of UNJ as follows: "It (raiding the church) is not justified. It may be done by a person or in the name of Islam."

The respondents from Rohis High School (SMA) agreed with conducting violent raids against places of vice and evil cults but not against the church. Adni Adzkia of Rohis SMA 59 and Mohamad Aci, Vice Chairman Rohis Vocational High School (SMK) Negeri 75, stated the following:

“(About the raid on immoral places?) It was good. (If it's a raid on the church?) No. (Cult?) Yes. (Why) because of conflicts with the sharia. (Right there is the government?) ... Do not understand. "6

Mohamad Ali stated "(on raid) (I) agree with destruction of immoral place as its also forbidden (including cult-like Ahmadiyah). I do not necessarily agree. (for Church?) I do not agree (once looked uncertain). An immoral place was destroyed for (because) it may damage the young generation ... (So) it was a good move, (good) because it's an immoral place; there is nothing right. Everything is bad."

Additionally, the respon dents from the Youth Community Organization (OKP) agreed with conducting raids against immoral places but not against cults and the church. This was disclosed by Didi Setiadi, Chairman KNPI of Thousand Islands, who stated:

"(Raiding for immoral) Agrees. But if related to the church, I do not agree. The time of the Prophet is also not allowed. (However) a cult, yes; there is fighting since the time of the Prophet, too. In Indonesia, it should be adjusted in a way so that they can be good. To directly raid the Ahmadiyah is good because they do have an understanding that is considered right by them." ${ }^{8}$

Basically, respondents did not approve of violent behavior towards the church. According to some respondents, violence or raiding church buildings usually occurs when the establishment of the church is not in accordance with existing rules, thus giving rise to a reaction from the surrounding community. When these reactions are not quickly and adequately settled by the government, it eventually leads to violence. This view is consistent with the narrative of the Governor of the youth mosque in North Jakarta. He stated the following:

"We should refer to the rules. We see laws. The Pendirin church sometimes does not follow the rules, but it is still standing. As a result, the community reacted. Sometimes the church is built on the site (environmental) of a Muslim community. Therefore, you should adjust the legislation. If the establishment of the church is done by the rules, it does not matter. They also have the right to worship.

Similar feelings were expressed by officials of the LDK UNJ. A respondent stated:

"Cases of violence (destruction) against the church occur because the existing rules/obligations are violated or because there is a person who intentionally wants to create a chaotic atmosphere. 
If the (church establishment) has been permitted (by the rules), there should be no violence. We must respect each other. If there are any problems, the path of deliberation should take precedence."

The views of the respondents with respect to violence against immoral places ${ }^{9}$ seem different than their views on violence against the church. A small portion of respondents agreed with this type of action without any conditions. This attitude was shown by respondents from among the group of Rohis who attended high school. Most respondents agreed with this type of action but with a number of conditions. The respondents who had this view said that the phenomenon of violence against immoral places occurs as a result of the half-heartedness and lack of government enforcement of laws that have established order in the society. The respondents considered the raiding of immoral places a reaction of a group of people to the government's inability to deal with the rampant immorality in society. The respondents seemed to take a middle position on conducting raids on immoral places. They did not expressly support such behavior, but they also did not directly blame the perpetrators for the behavior. A respondent from the LDK UI revealed the following:

"Most respondents do not agree with raiding places of worship (church) because it violates the worshippers' rights. Raiding immoral places disrupts public order because the government is unable to take firm action. This is a form of reaction from the public. We cannot directly blame them."

The same narrative was also conveyed by the board mosque youth in North Jakarta. He stated the following:

"Raiding against immoral places is a phenomenon that is almost the same as conducting violence against the cult. It is a form of forbidding the evil committed by a group of people because law enforcement does not function effectively. Finally, it's the community itself that (takes action to close the immoral place)."

Respondents from the FPI and the MUI had very similar views on violent acts against immoral places. Both respondents signaled that we cannot blame the people with respect to this case because this is a reaction to law enforcement's ineffectiveness. FPI leaders said that violence against immoral places occurs because the law is not enforced, while respondents from the MUI revealed that they do not blame people if they conduct raids against immoral places.

The respondents' narratives about violence against cults were similar to those regarding the phenomenon of violence against immoral places. The respondents were not directly and unequivocally blaming the people who committed the acts of violence against a group of people who they considered had gone astray. In the case of a cult, the respondents felt that there have been acts of harassment that have caused unrest or that have been offensive to the religious community (Islam). Here is the actual root of the problem. The respondents highlighted the issue of the government not taking strong actions against individuals in these cases, which has led to people having to overcome their own issues. Related to this view, the respondents from LDK UI revealed the following:

"I see people feel disturbed (by the cult). The government does not (cannot) be trusted to solve this problem. (A cult phenomenon) causes interference, because of the harassment of things that are considered sacred."

A board teenager from the North Jakarta mosque stated the following:

"In general, raids or acts of violence cannot be justified. We must have orderly law. Governments are supposed to curb cases of cults since this is already considered as a

9 Immoral places here may be defined as places for prostitution or entertainment that provide alcohol and encourage drunkenness. 
desecration of religion. So, I see law enforcement as ineffective in dealing with this issue. So, violence is a form of reaction from the public. Communities do this as part of efforts to prevent evil.

Furthermore, LDK of UNJ also said the following:

"We should firmly oppose (the cults), such as the Ahmadiyah or Shia ${ }^{10}$. The problem is that they claim Islam but have deviated from Islamic principles. So, this (is already categorized) as an abuse of Islam. The government should address this issue. If the government effectively addresses this issue, it will not happen (violence against the cult committed by a group of people)."

In addition to the narrative as exposed above, some respondents argued that any form of violence should not happen because it would damage the image of Islam and therefore the perpetrators must be dealt with. Such views emerged from respondents in the FKUB and the PKS, and from PKB party figures. On the other hand, two respondents who agreed with raids on immoral places noted that such actions should be conducted by the government/state, not by a person or group of people. This attitude was reflected by respondents from the KAMMI and the GPI. The views of the last group of respondents are consistent with the rule of law related to the raiding phenomenon and to violence.

Perhaps one of the most vicious and violent cultures in Jakarta is contained in the groups that have felt or perceived that they have experienced discrimination. When all their economic and political mobility is hampered, in particular because of the important position occupied by "settlers" in Jakarta, then those of certain ethnicities have no place to which they can return. This is the same as it is in the case of religion.

Thus, in Jakarta, various events at which there are clashes often involve community-based organizations' regionalism. Although often covered up with impressive preaching, a number of these events have attracted news media coverage. For example, there have been conflicts of interest between the Betawi and the Madura in Kebayoran Lama Market, the Banten and the Flores in Tanah Abang, and others. Even events in the Kebayoran Lama Market have sparked a reaction from a large number of citizens and Betawi leaders, which has led to the establishment of the Forkabi organizations in Jakarta.

Despite the fact that current conditions tend to be favorable, infighting among various organizations, such as Latar Kembang and FBR, is still possible because it has been traumatic for both groups. After peace between the two groups was initiated by the police of Jakarta, the two organizations took a defensive stance. As explained above, the events did not necessarily eliminate the cultural strategy which asserts that the culture has to "defend itself." The dynamics of the remaining mass organizations are that they are growing, sometimes violently.

\subsection{Narrative on Terrorism}

There was a mostly similar narrative from all respondents with regard to their views on terrorism. Generally, respondents viewed terrorism as not being consistent with Islamic teachings. Terrorism is a form of misunderstanding of Islam, and became counterproductive to Islam. The respondents provided an ambiguous assessment regarding the perpetrators of terrorism. In addition, there was another narrative pattern that emerged that was not reflected by all respondents, i.e., a belief that terrorism is a kind of conspiracy perpetuated by outsiders who dislike Islam.

\subsection{Terrorism Is Not in Accordance with Islamic Teachings}

All respondents had similar views about terrorism. They tended to say that terrorism is not consistent with the teachings of Islam. Islam is a rahmatanlilalamin religion, that is, a mercy for all

10 Shia was criticized in terms of the respondent's understanding of Shia leadership (Imam) and congregation, who adhered to the hierarchy system, while the Ahmadiyah cult views Mirza Ghulam Ahmad as a Prophet, not only as a reformist (mujaddid). 
creatures. This means that Islam provides noble teaching and aims to create a good life in the universe. It is not possible for Islam to teach meanness and cause horrible damage. The beneficence promoted by Islam is not only for human beings but also for all natural living things that exist in the universe. All respondents coming from the Rohis group in senior high school and youth organizations, such as KAMMI, GPI, and KNPI, agreed that terrorism is not in accordance with the teachings of Islam. The same view was also expressed by respondents from the MUI and FPI groups. When asked about the relationship between terrorism and Islam, the Islamic Mission organizations UI figures stated, "Terrorism is not in accordance with the teachings of Islam." Furthermore, the board of the north Jakarta mosque youth association in an interview said that "Islam is a religion rahmatan lil 'alamin; Islam is a peace religion." This view was reinforced by a narrative of another board member of the mosque youth association. He stated: “... Islam is rahmatanlil 'alamin. It has never been a war in peaceful circumstances. Terrorism is not in accordance with Islamic teachings. Making terrorism is jihad, but actually it's not."

Therefore, it is impossible for Islam to promote terrorism, an activity that causes damage or injustice to others. Actions of terrorism are essentially not consistent with the teachings and behavior of Islam. Therefore, even if there are Muslims who commit terrorist actions, they are persons who have a misconception of Islam. When mosque youth respondents were asked who the perpetrators of terrorism are, they said "they could be Muslims, but they have a superficial understanding of Islam. This is a deviation from real Islam." Such conditions have existed for a long time in every religion. A narrative stating that terrorism is not in line with Islamic teachings also has been affirmed by Islamic Mission organizations leaders of UNJ. One respondent stated, "(Terrorism) is not in accordance with the teachings of Islam. Islam does not teach terrorism. Islam does not condone terrorism. Islam is a doctrine of affection."

Terrorism cannot be generalized only to Islam. Indeed, terrorism can exist in any religion. It has appeared as a model of misconception in the interpretation of religious teachings. According to a number of respondents, terrorism is the result of dissatisfaction with conditions or reality, for example, injustices, poverty, and slavery. This was conveyed by a prominent figure of the LDK UNJ in the following statement:

"The behavior of terrorism arises because there is injustice, rampant immorality and some people who use illegal ways to fight for justice; it is not related to Islam. I do not agree that terrorism is related to Islam."

Cogent religious instruction should be developed as an education-based deradicalization program that distinguishes Islam from Islamism, addresses overlaps between Salafism and mainstream Sunnism, and appropriately responds to grievances over Western military interventions in Muslim-majority countries, including democratic means of opposing such action, to which governments will need to be meaningfully responsive (Rane 2019, p. 19).

\subsubsection{Terrorism: A Misconception Model in Understanding Islam}

The first narrative emerging from respondents about terrorism is that terrorism is not consistent with Islamic teachings. Islam has a mission of virtue for the universe. If it is acknowledged that a perpetrator of terrorism was a Muslim and that he fought in the name of Islam, then undoubtedly the perpetrator's understanding of Islam is wrong.

Therefore, the terrorists misunderstood the meaning of jihad. This is a summary of the views collected from some respondents. For instance, a respondent from PKB clearly stated that, as the terrorists misunderstood their religion, they went the wrong way, and they should be reproached. A young leader of the LDK UI considered that Islam does not have a positive impact on terrorism and that if it is proved that a terrorist is a Muslim, then it is probable that there is a problem in the person's understanding of Islam. The UI LDK Chairman stated the following: 
"I do not know what he (terrorist) is fighting for. There is no proof that Islam affected him.

There is a wrong understanding about Islam. There are still other ways."

The same thing was also spoken by a respondent from an association for mosque youth. He stated the following:

Terrorism is a form of simplifying religion. They misinterpret the meaning of jihad ...... it seems like jihad, but it is not ... ... This is a deviation from Islam. Such conditions have existed for a long time, and they exist in all religions.

\subsubsection{Terrorism Is Counterproductive for Islam}

The next narrative about terrorism conveyed by the respondents was an outlook that terrorism can create a bad image for Muslims. When the perpetrators (terrorists) think that terror is one of the methods that can be used to fight for Islam, their view is precisely opposite from the way Muslim people think. The respondents think that terrorism does not improve the image of Islam. Most of the respondents from Rohis in senior high school and all the respondents from the youth organizations (KAMMI, GPI, KNPI) agreed that terrorism does not improve the condition of Muslims. They assert that there is no correlation between terrorism and improvements in Islam. One young leader of Islamic rohani said that there might be some effects of terrorism that result in the improvement of the conditions of Muslims, but he still does not agree with the terrorists' actions.

The view that terrorism does not produce a positive impact on Islam was also delivered by a respondent of the mosque youth in northern Jakarta. He stated that terrorism could not produce good improvements for Muslims and could even worsen the image of Islam. In an interview, he said the following: "It (terrorism does not fix the Muslims). It will only worsen the image of Muslims in the eyes of the world."

The same response was delivered by a young leader of the LDK UI. He said the following: "It is an ideological question (it depends on who answers the question). In my opinion, (terrorism does not improve the condition of Muslims)."

\subsection{Ambiguous Attitude in Assessing Terrorists}

There were two narrative patterns reflected by the respondents with respect to terrorists, such as Amrozi, Imam Samudra, and Noordin M. Top ${ }^{11}$. First, from a negative viewpoint, there was disapproval of the lack of investigation with respect to the terrorists. This view emerged from most of the leaders of the Rohis in the high school and all respondents of youth organizations, such as the Youth Islamic Movement (GPI), the National Front of Indonesian Muslim Students (KAMMI), and the National Committee of Indonesian Youth (KNPI). The following comment was provided by Mohamad Ali from Pondok Karya Pembangunan Jakarta Islamic High School:

"(Regarding the bombers, such as Amrozi, Nordin M Top. Do you agree with them?) ... well I agree. (what's the reason?) ... because they are Muslims. (or maybe because the victims are infidels?) Not really, because there are Muslim victims. (Then why do you agree?) ... I do not know ... (the bombers admitted that they desired martyrdom. do you agree with them?) ... No, since their reasons are not based on a fight for Islam. (They said they did it on the name of Islam?) ... They did not fight for the sake of Allah. (So where are they?) Ehhh ... (silence, red). (do they only look for sensation/attention?) ... yes, they do."12

The second view is one of disagreement with the actions of terrorists but of appreciation for certain cases, for example, for the fighting spirit with respect to Islamic preaching. However, these respondents

11 Amrozi and Imam Samudra was executed for terrorism actions in the case of the Bali Bombing, 2002, and Noordin M Top was shot and killed in Solo, 2009.

12 Mohammad Ali, September 15, 2014. 
still considered that the terrorists misunderstood Islam and the jihad concept and had taken a wrong direction. The respondents who took this view could not say what the fate of the terrorists would be when judged in front of God. A respondent from the Islamic Mission organization UI, for example, said that she could not assess how the terrorists' actions would be viewed by God. In an interview, she said the following: "Let it be the Lord's business. I do not think about it too much. It's God's business. I do not take into account God's business."

Similar views were also expressed by the respondent Didi Setiadi, the Chairman of the National Youth Committee Organization (KNPI) of Kepulauan Seribu, that he did not agree with terrorism; however, he also agrees with certain issues, as he stated the following ${ }^{13}$ :

"Actually, terrorism is an attitude of dissatisfaction with a society that tolerates injustice. In certain matters, it is in accordance with Islam, but the implementation is not appropriate ... . (An appropriate thing is like developing the community?) Yes, it is. In the case of sharia enforcement, it would be better if it had been done using hands. It amounted to a situation that was fought at any cost ... (is it similar to what Amrozi has done?) I don't think so. In that case, Amrozi had the wrong understanding, because what he did caused a lot of people to suffer, even innocent people."

Another respondent from the mosque youth gave the same view. He stated the following:

"The assessment of Amrozi and his friends is very dependent on what point of view is used. I cannot judge (assess) him as an infidel or martyr. It was the authority of God; even though apparently it was wrong, I cannot judge."

Unlike the mosque youth, respondents from the Rohis in senior high school and all youth organizations openly said that they did not agree with the terrorists and that they object to labeling terrorists as martyrs. This means that they believe terrorists are wrong and that the terrorists are valued negatively before God, the Almighty.

\subsection{Terrorism Is a Conspiracy}

A small portion of respondents believes that terrorism is a conspiracy of certain parties to intervene in Indonesia to impose Islam. This view appears only in a minority of respondents, i.e., one respondent from LDK and one respondent from the mosque youth. They judge that it is not clear who the real perpetrators of terror are, and they think the terrorists require a large amount of funds and high technology to carry out their large bombing missions, which would not be possible if done by a small group of people. They suspect that there is a strong party who has sponsored terrorism. A figure of Islamic Mission organizations UNJ indicated this allegation. He stated the following:

"I see that there are (some) irregularities in the arrests of terrorism. Perhaps this is a conspiracy to discredit Islam. Terrorism is everywhere and in any groups and religions. Terrorism cannot be generalized (to Muslims). Many cases are claimed to be acts of terrorism but are not openly and clearly processed at the court (they were killed in an ambush, so we cannot know who really they are). Perhaps this is part of a conspiracy (to give a bad image of Islam and or to control the development of Islam)."

The same view was also delivered by a prominent mosque youth in North Jakarta, who said the following:

"Who is Amrozi? He is nothing. It was deliberately created by the Americans in order to control Indonesia. Indonesia is an easy country to control. There are people who provide

13 Didi Setiadi. 2014. September 15, 2014. 
funds and the amount is very large. The price of bombs is expensive, and an ojek rider may not be able to purchase a bomb. It has been financed by the United States. It is the American effort to control Indonesia, as it did to Iraq and other countries."

What can be concluded is that, in general, the research conducted on this topic shows that the majority of the respondents' views are generally moderate. The theme of the respondents' narratives resembles that of the "polarized radical," covering such topics as who is the enemy of Islam, Western products, the church, and raids. In analyzing sample responses consistent with this radical narrative, we found that the Rohis cluster exhibited a relatively strong correspondence. However, we also noted an emphasis of the vulnerable, not on those born in Jakarta. This could mean that the narrative of radicalism is not one of a radical who is a native of Jakarta, or of radicalism carried out by residents of Jakarta, just because the conditions giving rise to radicalism began in Jakarta.

The research shows that, generally, the narrative map of respondents in Jakarta with respect to violence and terrorism clusters into certain groups. Most respondents did not indicate radical responses in their views about the state, sharia law, political system, violence, non-Muslim groups (the other), etc. This map shows that the narrative of respondents does not reflect any condition that is reason for concern, and shows no significant potential for radicalism and terrorism.

\subsection{Patterns of Narrative Deployment}

Theoretically, the narrative deployment of radicalism and terrorism is based on certain patterns. In other words, the construction of the narratives is not the same for all characters and all clusters. The spread of the radicalism and terrorism narratives is due to several factors with respect to patterns and mechanisms:

1. Electronic and printed media, such as TV, radio, movies, newspapers, newsletters, flyers, internet, social media, and others;

2. Teaching, meeting (khalaqah), and others;

3. Demonstration, humanitarian action, and others;

4. Interpersonal relations through family, friendships, and organizations; and

5. Teaching through the school curriculum, boarding schools, and others.

We can see five patterns and means for the deployment of radicalism and terrorism narratives; the easiest and most far-reaching deployment is through TV, radio, the Internet, and social media. The most difficult to control is the narrative deployed through social media because everyone can spread the narrative at any time and from wherever they are located. Based on the research, the data obtained can be seen in Table 1. 
Table 1. Patterns of Radicalism and Terrorism Narrative Deployment in Jakarta Metropolitant: Religious Leaders, Community Leaders and Political Leaders.

\begin{tabular}{|c|c|c|c|c|c|c|}
\hline \multirow[b]{2}{*}{ Narrative/Theme } & \multicolumn{2}{|c|}{ Religious Leaders } & \multicolumn{2}{|c|}{ Community Leaders } & \multicolumn{2}{|c|}{ Political Leaders } \\
\hline & $\begin{array}{l}\text { Islamic Defeated } \\
\text { Front (FPI) }\end{array}$ & $\begin{array}{l}\text { Indonesian Council } \\
\text { of Ulama (MUI) }\end{array}$ & $\begin{array}{c}\text { Confederation } \\
\text { Forum of Betawi } \\
\text { Association (Bamus } \\
\text { Betawi) }\end{array}$ & $\begin{array}{l}\text { Religious Harmony } \\
\text { Forum FKUB }\end{array}$ & $\begin{array}{l}\text { The Prosperous } \\
\text { Justice Party (PKS) }\end{array}$ & $\begin{array}{c}\text { National Awakening } \\
\text { Party (PKB) }\end{array}$ \\
\hline $\begin{array}{l}\text { Early religion } \\
\text { understanding }\end{array}$ & $\begin{array}{c}\text { Sunni } \\
\text { Ahlussunnah } \\
\text { Waljamaah non NU }\end{array}$ & $\begin{array}{c}\text { Sunni } \\
\text { Ahlussunnah } \\
\text { Waljamaah non NU }\end{array}$ & $\begin{array}{c}\text { Sunni } \\
\text { Ahlussunnah } \\
\text { Waljamaah without } \\
\text { affiliatiton }\end{array}$ & $\begin{array}{c}\text { Sunni } \\
\text { Ahlussunnah } \\
\text { Waljamaah } \\
\text { without affiliatiton }\end{array}$ & Sunni/Muhammadiyah & Sunni/NU \\
\hline $\begin{array}{l}\text { Variannt of } \\
\text { Construction }\end{array}$ & moderate Islam FPI & Radical Islam & Ritualist Islam & Modernist Islam & Islam kaffah & Seculer Islam \\
\hline $\begin{array}{l}\text { Problems of } \\
\text { Muslims, the } \\
\text { enemies of Islam } \\
\text { and others }\end{array}$ & $\begin{array}{c}\text { Pattern of } \\
\text { deployment through } \\
\text { the media (TV, } \\
\text { newspapers, internet, } \\
\text { social media, etc.) }\end{array}$ & $\begin{array}{c}\text { Pattern of } \\
\text { deployment through } \\
\text { the media (TV, } \\
\text { newspapers, internet, } \\
\text { social media, etc.) }\end{array}$ & $\begin{array}{c}\text { Pattern of } \\
\text { deployment through } \\
\text { the media (TV, } \\
\text { newspapers, internet, } \\
\text { social media, etc.) }\end{array}$ & $\begin{array}{c}\text { Pattern of } \\
\text { deployment through } \\
\text { the media (TV, } \\
\text { newspapers, internet, } \\
\text { social media, etc.) }\end{array}$ & $\begin{array}{c}\text { Pattern of } \\
\text { deployment through } \\
\text { the media (TV, } \\
\text { newspapers, internet, } \\
\text { social media, etc.) }\end{array}$ & $\begin{array}{c}\text { Pattern of } \\
\text { deployment through } \\
\text { the media (TV, } \\
\text { newspapers, internet, } \\
\text { social media, etc.) }\end{array}$ \\
\hline $\begin{array}{l}\text { Islam, State and } \\
\text { politic }\end{array}$ & $\begin{array}{l}\text { Patterns of halaqah } \\
\text { and liqa' and teaching }\end{array}$ & $\begin{array}{l}\text { Patterns of halaqah } \\
\text { and liqa' and teaching }\end{array}$ & $\begin{array}{l}\text { Patterns of halaqah } \\
\text { and liqa' and teaching }\end{array}$ & $\begin{array}{l}\text { Patterns of halaqah } \\
\text { and teaching }\end{array}$ & $\begin{array}{l}\text { Patterns of halaqah, } \\
\text { liqa' and teaching }\end{array}$ & $\begin{array}{l}\text { Patterns of halaqah, } \\
\text { liqa' and teaching }\end{array}$ \\
\hline $\begin{array}{l}\text { Violence and } \\
\text { radicalism }\end{array}$ & $\begin{array}{l}\text { Dispersal patterns } \\
\text { through the media } \\
\text { (TV, newspapers, } \\
\text { halaqah, internet, } \\
\text { social media, etc.) }\end{array}$ & $\begin{array}{l}\text { Dispersal patterns } \\
\text { through the media } \\
\text { (TV, newspapers, } \\
\text { halaqah, internet, } \\
\text { social media, etc.) }\end{array}$ & $\begin{array}{l}\text { Dispersal patterns } \\
\text { through the media } \\
\text { (TV, newspapers, } \\
\text { halaqah, internet, } \\
\text { social media, etc.) }\end{array}$ & $\begin{array}{l}\text { Dispersal patterns } \\
\text { through the media } \\
\text { (TV, newspapers, } \\
\text { halaqah, internet, } \\
\text { social media, etc.) }\end{array}$ & $\begin{array}{l}\text { Dispersal patterns } \\
\text { through the media } \\
\text { (TV, newspapers, } \\
\text { halaqah, internet, } \\
\text { social media, etc.) }\end{array}$ & $\begin{array}{l}\text { Dispersal patterns } \\
\text { through the media } \\
\text { (TV, newspapers, } \\
\text { halaqah, internet, } \\
\text { social media, etc.) }\end{array}$ \\
\hline $\begin{array}{l}\text { Radicalism and } \\
\text { terorism }\end{array}$ & $\begin{array}{l}\text { Dispersal patterns } \\
\text { through the media } \\
\text { (TV, newspapers, } \\
\text { halaqah, liqa', teaching, } \\
\text { internet, social } \\
\text { media, etc.) }\end{array}$ & $\begin{array}{l}\text { Dispersal patterns } \\
\text { through the media } \\
\text { (TV, newspapers, } \\
\text { halaqah, liqa', teaching, } \\
\text { internet, social } \\
\text { media, etc.) }\end{array}$ & $\begin{array}{l}\text { Dispersal patterns } \\
\text { through the media } \\
\text { (TV, newspapers, } \\
\text { halaqah, liqa', teaching, } \\
\text { internet, social } \\
\text { media, etc.) }\end{array}$ & $\begin{array}{l}\text { Dispersal patterns } \\
\text { through the media } \\
\text { (TV, newspapers, } \\
\text { halaqah, teaching, } \\
\text { internet, social } \\
\text { media, etc.) }\end{array}$ & $\begin{array}{l}\text { Dispersal patterns } \\
\text { through the media } \\
\text { (TV, newspapers, } \\
\text { halaqah, liqa', teaching, } \\
\text { internet, social } \\
\text { media, etc.) }\end{array}$ & $\begin{array}{l}\text { Dispersal patterns } \\
\text { through the media } \\
\text { (TV, newspapers, } \\
\text { halaqah, liqa', teaching, } \\
\text { internet, social } \\
\text { media, etc.) }\end{array}$ \\
\hline
\end{tabular}


The deployment of radicalism and terrorism narratives is still achieved through the old pattern of halaqah, that is, through recitals by sitting in a circle, and though liqa', that is, a meeting to recite. In addition, massive deployment has been accomplished through the media (TV, newspapers, the Internet, social media, etc.). The pattern of the spread of the radicalism and terrorism narrative that is the most difficult to control is through social media, because everyone is capable of this type of deployment and social media users globally, the majority of which are the young generation, can become easy targets.

In the context of the mosque, the religious narrative and political identity can also be spread through various mediums. Because some groups are closely related to the community and places of a religious nature, most of the distribution pattern is conducted traditionally. Here, routine activities, such as Friday sermons, weekly or monthly lectures, or other religious events, are important.

For example, at Masjid Baitur Rohim, the Friday sermon is given by dozens of different preachers. This practice corresponds to the mosque management (takmir) policy that only provides each preacher the opportunity to deliver a sermon (khutbah) once a year. Preacher's (khatib) are more reliable and preferably could be afforded the opportunity to give a sermon twice or maybe three times a year. Nonetheless, for the mosque, a system in which a sermon is given once a week, as in other areas, is not customary.

Thus, it is somewhat difficult to determine where and how the pattern of the narrative spreads. However, as explained by Mr. Sonih, a mosque takmir, there is an evaluation delivered every week by the coordinator for the observance of religious duties. ${ }^{14}$ Sometimes, the congregation members themselves will contact the mosque committee by phone or Short Massages Services (SMS) when there are some less suitable or difficult matters to discuss. Periodically, mosque officials gather to discuss different issues, ranging from the condition of the mosque, the income from donations and kencleng (charity box), the content of speech, and the style of the preachers and propagators when delivering a lecture at the mosque.

Kebon Jeruk Mosque, one of the historic mosques in Jakarta, has long been recognized as one of the centers reflecting the spread of the Islamic missionary JamaahTabligh movement models. According to Ustadz Hanif, one of the activists of Jamaah Tabligh Pondok Ranji, the mosque is open to anyone. The communication of teachings and understanding is accomplished by regular meetings in this mosque. There are congregants who come once a week, twice a week, or only at certain times. They come from all over the Greater Jakarta area (Jabodetabek) and include those who come from other regions in Indonesia. In addition, any group that has a strong commitment to the Jamaah Tabligh movement will be given an opportunity to gather in small groups and then to do itinerant preaching-a practice called khuruj-with a well-planned time schedule, travelling around the village or town, or outside the city. When I (FS) met Ustadz Hanif, he claimed that he was planning a preaching tour to Papua. Several years before, he had been preaching in India, Pakistan, and Bangladesh. ${ }^{15}$

The spreading of narratives and teachings among Tabligh members has been accomplished by calling people to worship in the mosque. The more people there are who move back to the mosque, the more they can spread their narrative. For that reason, Jamaah Tabligh is called a non-political Islamic movement. Some people are interested in joining the mosque in this way. After joining, they usually meet with other people who are newcomers in Jamaah Tabligh and begin their journey in preaching. Ustadz Hanif is very happy with this method of spreading his teaching. Moreover, he can meet with some people who he has never known before, in a situation that is very friendly, warm, and dignified, and in a place of worship. Ustadz Hanif revealed that this method and pattern of spreading his teaching attracted a number of members of the Muslim community to join Jamaah Tabligh and stated one other fact: former military and police officials, artists, and well-known musicians,

14 Sonih, M. 2014. October 11, 2014.

15 Ustadz Hanif. 2014. “Dialog PencegahanTerorisme” FKPT-Tokoh Agama Hotel Sofyan Betawi. Saturday, November 15, 2014. 
as well as ordinary people, are some of his congregants. Bang Sonih, who is now serving as chairman of mosque takmir in Bintaro, admitted that he repeatedly follows itinerant missionary activities together with Jamaah Tabligh activists who come to his mosque. Therefore, he welcomes the members of the Jamaah Tabligh to stay and to preach in his mosques and territory.

At the As-Sakinah mosque, located in a residential complex in the border area of Jakarta and Banten, the pattern of the spread of the Islamic narrative has been one of a deployment focused on children and mothers. The reason for this is because men were usually at work when Islamic teaching was occurring. Ustadz Anwar, who served there, was a young indigenous Betawi man staying in the local village. When he was asked where he received his religious education, he said that he only learned from experience because he diligently attended the teachings of the youth in his village. ${ }^{16}$ Ustadz Anwar is a graduate of a private high school in Tangerang city but was active in Islamic activities in that region.

When asked to name the preachers that regularly delivered sermons, he mentioned several names, one of whom was Ustadz Abu Jibril. According to him, he is very deeply religious, so he and his friends like to come to Ustadz Abu Jibri's sermons in South Tangerang, although his sermons are not scheduled. When Ustadz Abu Jibril was recently accused of being involved with extreme Islamic groups, he shrugged. He did not know if Ustadz was dealing with police and other authoritative institutions because of his religious teachings and understandings. What he knows is that he and his friends liked his speech style and feel satisfied with the religious explanations given by him.

At this point, the pattern of narrative deployment is not simple. Some are regular and periodic, while some are not fixed. In terms of the method, the deployment of the narrative is conducted in many ways depending on the parties involved, both giver and receiver.

\subsection{Pattern of Narrative Reception}

The radicalism and terrorism narrative has not been accepted by the people of Jakarta, but it has not been absolutely rejected. The narrative has undergone a process of maximum transformation, but the acceptance of this narrative has not substantively succeeded. Based on a pick-test sample in Table 2, it can be seen that the pattern of narrative reception can occur in the following ways: by accepting the substance of the narrative (thesis) offered by a radical/terrorist group; by opposing the narrative (antithesis) offered by a radical/terrorist group; and by improving the narrative (improver/synthesis) offered by a radical/terrorist group.

Based on the findings in Table 2, 62 of 96 respondents reflected attitudes that refused to embrace the negative narrative in the theme of radicalism and terrorism, which means that $64.58 \%$ of the respondents would act in a way that would be the antithesis of the narrative. The remainder of the responses are divided as follows: attitudes accepting the narrative, 14 respondents (14.58\%); accepting attitude for the narrative but with improvements, 5 respondents $(5.20 \%)$; and taking a neutral position, while improving it, 15 respondents $(15.62 \%)$. Based on the findings from the data, it can be concluded that the majority of the research respondents reject radicalism and terrorism.

16 Anwar. 2014. Agustus 15, 2014. 
Table 2. Reception Pattern of Radicalism and Terrorism Narrative in Jakarta Metropolitant: Rohani Islam (Rohis) and Youth Community Organisation (OKP) Cluster

\begin{tabular}{|c|c|c|c|c|c|c|c|}
\hline \multirow{2}{*}{\multicolumn{2}{|c|}{ NARRATIVE/PATTERNS OF RECEPTION }} & \multicolumn{3}{|c|}{ Rohani Ialam Cluster } & \multicolumn{3}{|c|}{ Youth Community Organization OKP Cluster } \\
\hline & & SMA N 59 & SMK N 75 & SMA PKP JIS & KAMMI & GPI & KNPI \\
\hline \multirow{5}{*}{$\begin{array}{l}\text { The present } \\
\text { situation and "the } \\
\text { others" issues }\end{array}$} & Enemy of Islam & accept & accept & accept & accept & accept & accept \\
\hline & The other & Opposesse & Opposition & Opposition & Opposition & Opposition & Opposition \\
\hline & Non Muslim & Opposition & Opposition & Opposition & Opposition & Opposition & Opposition \\
\hline & Western product & accept & Improver & accept & Opposition & Opposition & Opposition \\
\hline & curch & accept & Improver & accept & Opposition & Opposition & Opposition \\
\hline \multirow{6}{*}{$\begin{array}{l}\text { Islam, State } \\
\text { and politik }\end{array}$} & Democration & Opposition & Opposition & Opposition & Opposition & Improver & Improver \\
\hline & Pancasila & Opposition & Opposition & Opposition & Opposition & Opposition & Opposition \\
\hline & NKRI & Opposition & Opposition & Opposition & Opposition & Opposition & Opposition \\
\hline & The enforcement of Islamic Sharia & Opposition & Opposition & Opposition & Improver & Opposition & Opposition \\
\hline & The current government category & Improver & Improver & Improver & Improver & Improver & Improver \\
\hline & Islamic State of Indonesia & accept & accept & accept & Improver & Improver & reject \\
\hline Violence & Sweeping/violence act & $\begin{array}{c}\text { accept } \\
+ \text { Improver }\end{array}$ & $\begin{array}{c}\text { accept } \\
+ \text { Improver }\end{array}$ & accept & Improver & Improver & $\begin{array}{c}\text { accept } \\
+ \text { Improver }\end{array}$ \\
\hline \multirow{4}{*}{ Terorism } & Terorism is fitted with Islam & Opposition & Opposition & Opposition & Opposition & Opposition & Opposition \\
\hline & $\begin{array}{c}\text { Terrorism and community } \\
\text { improvement }\end{array}$ & Opposition & $\begin{array}{c}\text { accept } \\
+ \text { Improver }\end{array}$ & Opposition & Opposition & Opposition & Opposition \\
\hline & Sympathy for terrorists & Opposition & Opposition & $\begin{aligned} & \text { accept } \\
+ & \text { Improver }\end{aligned}$ & Opposition & Opposition & Opposition \\
\hline & Teroris adalah mati syahid & Opposition & Opposition & Opposition & Opposition & Opposition & Opposition \\
\hline
\end{tabular}


Although the percentage of respondents accepting the radicalism and terrorism idea ranges between $14 \%$ and $19 \%$, it does not mean that there is a potential threat in Jakarta. Because radicalism and terrorism activities generally are not conducted by large numbers of people, these concepts are not contemplated in the minds of the majority of the public. The terrorists are usually more of a militant, controlling minority.

The balance between the percentage of the group who accepted the narrative and the group who would have improved it indicated a balanced view in the society of the activists and negative narratives. This means there is a socio-political tendency to stem the tide of radicalism and terrorism. In other words, the people of Jakarta are smart enough to see what is good and bad relating to life and society, despite the use of the label of religion (Islam) linked with terrorism as a provocative issue.

Some sensitive narratives, for example, narratives concerning "the other" and non-Muslims, reflect the refusal of the respondents to accept narratives that are diametrically opposed to their view of Islamization. This indicates that there is a religious and social maturity. A somewhat risky issue concerns raids against immoral places and misleading Islamic sects and churches. Although the church is considered a safe place that should not be raided, immoral places are considered as objects that deserve to be destroyed by force. This can be seen positively as a degree of participation by the religious communities in rejecting the existence of a place that is going to demoralize their moral and social order. Therefore, the role and presence of the government in quickly responding to the existence of these immoral places is important.

The pattern of the spread and acceptance of narratives is also very closely related to the presented content and material. At a mosque in Bintaro, South Jakarta, a terrace board member of the mosque said that sometimes there is a Friday preacher or speaker with a rather "hard" manner of speaking. Hard here certainly does not refer to volume but rather refers to the content of the speech. According to the board member, there are some preachers or speakers talking loudly, indiscriminately, and uncompromisingly-especially when it is about religious teachings. If something is true, they say that it is true; if wrong, they say that it is wrong. There is no grey area in religion. During the New Order, Betawi people often termed such speech as sedep, or savory, meaning that it was pleasing, as in the taste on the tongue. This type of speaker received a great deal of attention from people since, in the New Order era, political openness was taboo and, in part, because of the particular communication medium, such as recitation.

The contents and teaching materials or sermons that are considered to be hard are approved by mosque committees because, to be religious, it is important to be assertive, straightforward, and not hypocritical. For example, having a certain attitude regarding issues, such as halal and haram, heaven and hell, is necessary. Nevertheless, the terrace board member was not very happy with the content of sermons or lectures that carry a political issue, or, moreover, that criticized other persons or parties personally. For such a preacher or speaker, he said he would make a note to be delivered in a meeting of the mosque board or to be submitted, either spoken or written, to the person in the section of worship who invited him. In this context, the type of religious ideology plays an important role in terms of the extent to which a narrative is accepted or rejected.

In addition to showing the pattern of the spread of the radicalism and terrorism narrative, we also expose the reception pattern of the radicalism and terrorism narrative. For more detailed information, a reception pattern of the radicalism and terrorism narrative is shown in Table 3. 
Table 3. Reception Pattern of Radicalism and Terrorism Narrative in Jakarta Metropolitant: Study of Religious Leaders, Community Leaders and Political Leaders

\begin{tabular}{|c|c|c|c|c|c|c|}
\hline \multirow[b]{2}{*}{$\begin{array}{l}\text { NARRATIVE/PATTERN } \\
\text { OF RECEPTION }\end{array}$} & \multicolumn{2}{|c|}{ Religious Leaders } & \multicolumn{2}{|c|}{ Community Leaders } & \multicolumn{2}{|c|}{ Political Leaders } \\
\hline & $\begin{array}{l}\text { Islamic Defeated } \\
\text { Front (FPI) }\end{array}$ & $\begin{array}{l}\text { Indonesian } \\
\text { Council of } \\
\text { Ulama (MUI) }\end{array}$ & $\begin{array}{l}\text { Confederation Forum of } \\
\text { Betawi Association } \\
\text { (Bamus Betawi) }\end{array}$ & $\begin{array}{c}\text { Religious } \\
\text { Harmony } \\
\text { Forum FKUB }\end{array}$ & $\begin{array}{l}\text { The Prosperous } \\
\text { Justice Party (PKS) }\end{array}$ & $\begin{array}{c}\text { National Awakening } \\
\text { Party (PKB) }\end{array}$ \\
\hline $\begin{array}{l}\text { The enemy of Islam } \\
\text { issues }\end{array}$ & comprehend & comprehend & comprehend & comprehend & comprehend & Comprehend \\
\hline The others issues & resist & resist & resist & resist & resist & resist \\
\hline Democration issues & exaggerated & resist & accept but exaggerated & accept & accept & accept \\
\hline Pancasila issues & $\begin{array}{l}\text { Accept but have not } \\
\text { practiced yet }\end{array}$ & $\begin{array}{l}\text { Accept but have not } \\
\text { practiced yet }\end{array}$ & accept & accept & $\begin{array}{l}\text { Accept and must } \\
\text { bet practiced }\end{array}$ & accept \\
\hline NKRI issues & No problem & No problem & No problem & No problem & No problem & No problem \\
\hline Sharia enforcement issues & Must & difficult & $\begin{array}{l}\text { Resist and it will } \\
\text { disintegrate nation }\end{array}$ & Psuedo resist & $\begin{array}{l}\text { Not attractive issue } \\
\text { for people }\end{array}$ & resist \\
\hline $\begin{array}{l}\text { Islamic State of Indonesia } \\
\text { issues }\end{array}$ & No problem & $\begin{array}{l}\text { Uneasy many } \\
\text { resistance }\end{array}$ & $\begin{array}{l}\text { Resist and it will } \\
\text { disintegrate nation }\end{array}$ & resist & Not attractive issue & resist \\
\hline Violence and radicalism & resist & resist & resist & resist & resist & resist \\
\hline Terorism issues & resist & resist & resist & resist & resist & resist \\
\hline
\end{tabular}


The reception pattern of the radicalism and terrorism narrative is similar in all groups and in various clusters, as seen in the responses about the enemy of Islam discourse. All groups understand narratives relating to enemies of Islam because it has been already stated in the Koran that Jews and Christians will never willingly follow Islam unless you follow them (al Baqarah (2): 120).

This is similar to the situation with respect to democracy issues, as religious leaders saw that indeed democracy is not compatible with Islam. The religious leaders felt that narratives relating to democracy had been "exaggerated." Some groups firmly reject democracy. Others may accept democracy, but its acceptance is not considered by people as being morally correct.

\subsection{Factors of Narrative Deployment and Reception}

However, if this assumption is accurate, note that some regions or areas in Jakarta often become "targeted operation" zones. These areas are the strategic business center, government, police, and diplomatic offices in Jakarta. Several bombing tragedies have occurred in those places, such as the bombings at the Hotel Marriott and the Australian Embassy.

The interesting point is that the targeting devices used in such operations were apparently often prepared in other areas, particularly in the outskirts of Jakarta. The Book Bomb, for example, was prepared by former Islamic activists who lived in Aceh Province (outside of Java) for a number of years and had also lived in Ciputat. The zone-targeted operation is also spreading, from Serpong and Tangerang to Utan Kayu and East Jakarta. In recent years, these terrorist groups also have scrutinized the outskirts of Jakarta as if they were looking for a new "hideaway." Usually, it has been located or adjacent to the Muslim community in Jakarta and its neighborhoods, which are considered ordinary neighborhoods, such as Bekasi, Bogor, Tangerang Selatan, Pamulang, and Ciputat—which have become terrorist ambush sites several times-and are even situated near Islamic higher education institutions.

In this study, because of the changes in the demographic map we paid special attention to the importance of the peripheral areas of Jakarta. Although no specific factors have yet been found with respect to the strengthening of Islamism, especially radicalism and terrorism, in a suburb of Jakarta, or in areas bordering Jakarta, there may be a social impact or a particular psychological effect on the citizens who are in this region and surrounding areas.

Radicalism and terrorism narratives have been deployed in the public curriculum. Unfortunately, the substance of the narrative is generally rejected because it is counterproductive to the community and not in accordance with Islam. How can the narrative spread and be accepted by $14.58 \%$ of the respondents? Several factors could be behind this.

First, consider the success factors of the narrative's dispersal. As seen in Table 2, there are six patterns for the spread of narration, in either a single or a collaborative way. Among the six patterns, the patterns of interpersonal relations are dominant. This indicates that the successful deployment of the narrative occurs because our society is content to socialize and to interact cohesively, both among citizens and within the family relationship. The strong public opposition and the attitude of the need for improvement of the community towards the radicalism narrative indicate that the people of Jakarta are not producers or constructors of such negative narratives that have spread to the people. The pattern of interpersonal relationships is the medium used to spread the secondary narrative. Therefore, it is important to look at the learning model (curriculum) and the patterns of the social setting used by the media produce the primary narrative of radicalism and terrorism.

Second, consider the success factors of the narrative's reception. The spread of the narrative is also most often caused by the respondents' attitudes towards accepting it. Several important reasons show success factors are due to a lack of understanding of Islam as a rahmatanlil' alamiin (peaceful) doctrine. The acceptance attitude in this study was reflected primarily in the Rohis group, which, in terms of education, is still on a long learning curve or, in other words, they are still unstable or have an incomplete and unfinished understanding of religion. Therefore, their attitude can be understood as a natural matter and a necessary protective action for them. The social setting factors, such as economic conditions, perceived injustices, corruption, and despotic leaders, may be factors triggering a successful 
reception of the narratives. Third, consider the factors of the narratives' rejection. It is interesting that the people of Jakarta have "an active antibiotic" when the radicalism and terrorism virus presents and infiltrates the Jakarta community. The opposition to the radicalism narrative generally comes from the OKP activists who have a counter-narrative based on their organization located in the area in which the narrative has spread. In addition, the internalization of the spirit of nationalism and the awareness factor of the Indonesian Islam model is considered a strong influence. Similar to the National Front of Indonesian Muslim Students (KAMMI) and the Youth Islamic Movement (GPI), Ahmad Zainudin stated the following:

"(is uncle salafi jihadist similar with GPI?) No, actually I am more open after joining the GPI.

I used to say bid'ah (heresy) to people who had a different belief. While after joining the GPI,

I became more tolerant in seeing a different paradigm."

The KAMMI and KNPI members have had similar experiences. Generally, they are activists who understand public policy. Therefore, the regulatory factors that apply to safety and law enforcement could also be a factor that helps them to refuse the narrative.

The five factors influencing the deployment and acceptance of the radicalism and terrorism narrative are as follows:

1. The social protests of economic and legal injustice.

2. Ideological encouragement to make changes.

3. The influence of the social environment and social association.

4. The effect of the global environment.

5. A minimal and incorrect understanding of religion.

These five factors could be driving factors in the spread and acceptance of radicalism and terrorism narratives. Therefore, religious leaders who were respondents in this study emphasized the importance of justice implementation, even justice with respect to the press. Fairness in the economic sector becomes a major issue in the deployment and acceptance of radicalism and terrorism. Other issues in deployment and acceptance include ideology factors, legitimacy, passion, determination, and even the spirit of struggle (jihad) to correct injustice. Justice factors are contained in the second and fifth principles of Pancasila.

The deployment and reception of radicalism and terrorism can be imported from areas in the Middle East, which continuously fuel the flames of radicalism and terrorism that are responded to by those who misunderstand Islam, have a lack of education, and who are poor. Through the media, they accept and spread the narrative of radicalism and terrorism.

\section{Conclusions}

Research on the narrative and the identity of politics, which we conducted in Jakarta Province, provided a wide perspective on the pattern of radicalism and terrorism in terms of the means and extent of their spread and acceptance in this region. Based on the findings in the field, the research conclusions can be summarized as follows:

1. The respondents of Jakarta have a diversity of narratives of radicalism and terrorism, but the majority of respondents have negative attitudes towards any violence and terrorism acts. Most of the respondents rejected the substance of the narrative offered by radicalism and terrorism narrative creators.

2. This study confirms that respondents of Jakarta are not the perpetrators of radicalism and terrorism. There is a diverse pattern in the spread and acceptance of these narratives. In general, it can be said that the people have a more moderate understanding. There are some views that tend to be militant; their views cannot be separated from the context of religious life, which is conservative but not necessarily radical, extreme, or even terroristic. 
3. Even though a small proportion of respondents tends to accept the narrative, there is at least an ambiguous attitude towards the issue of radicalism and terrorism; however, the respondents' attitudes need to be explained further, and accompanied by a strong reason relating to their attitude of reception. This acceptance may be merely a part of individual piety which-according to these respondents-must be shown in their religion. However, in general, respondents exhibit social piety in order to realize a peaceful social life.

4. There is a pattern in the spread of radicalism and terrorism in the history of activism, but there are several factors that do not increase radicalism or terrorism in activism movements; for example, educational and organizational maturity factors existing in the areas in which the activists are located, as well as in the social setting in Jakarta, actually result in some movements being opponents of the "attack" narrative. This explains why the radicalism and terrorism narrative is an "imported narrative," in which the actors are overwhelmingly the people who are culturally "strangers" or- to quote one respondent's term-“the foreigners" who come from outside Jakarta.

5. The electronic-printed media and social media have been used to spread the narrative of radicalism and terrorism in the midst of the Jakarta community. However, to date, the people of Jakarta have resisted all forms of radicalism and terrorism, which is proof that the perpetrators of radicalism and terrorism in Jakarta are not citizens of Jakarta. However, the spreading of news about injustices throughout the nation, including Jakarta, the ambiguous treatment by authorities of suspected terrorists, and the amount of radicalism and terrorism imported from outside (for example, the Middle East), can potentially affect and change the mindset and behavior of people of Jakarta. Thus, residents of Jakarta can be transformed from people who tend to support anti-violence, anti-radicalism, and anti-terrorism, to people who are permissive with respect to all forms of violence, and may even become perpetrators of radicalism and terrorism for implementing change. If this is allowed, there will be a rallying point (intersection) consistent with the themes of other radical movements, such as DII/TII, in various parts of Indonesia, which have their own political agenda.

6. To end the acts of radicalism and terrorism, the majority of respondents stated that it is impossible to resolve the problems of violence with violence. Thus, from this perspective, the "violence vis-à-vis violence" model is considered highly inappropriate. For the majority of the respondents, violence hereditarily propagates revenge and can create the seeds of new radicalism and terrorism.

7. The findings in this research falsified the thesis of Martin Van Bruinessen (2013). Thus, this study provided a new explanation for the political Islam narrative in the context of modern Indonesian politics.

Author Contributions: Conceptualization, F.S. and R.N.; methodology, F.S.; software, F.M.M.; validation, F.M.M., A.R.R. and R.N.; formal analysis, F.S.; investigation, A.R.R.; resources, R.N.; data curation, A.R.R.; writing - original draft preparation, F.S.; writing-review and editing, F.M.M.; visualization, R.N.; supervision, F.S.; project administration, A.R.R; funding acquisition, A.R.R. All authors have read and agreed to the published version of the manuscript.

Funding: This research was funded by FORUM KOMUNIKASI PENCEGAHAN TERORISME/ COMMUNICATION FORUM FOR TERRORISM PREVENTION (FKPT) DKI Jakarta, grant Year Fiscal Year 2013/2014 and "The FKPT was funded by Provincial (APBD) and National Bugdet (APBN) 2013/2014".

Acknowledgments: We would like to thank El Amry Bermawi Putera, Rector Universitas Nasional, Zainal Musappa, Asep Supena and Agus Riyanto from Communication Forum for Terrorism Prevention (FKPT), Jakarta 2013-2017.

Conflicts of Interest: The authors declare no conflict of interest for this publication. 


\section{List of Acronyms}

BAMUS Badan Musyawarah Masyarakat-Confederation Forum of Betawi Association

CBOs Community-Based organizations

DI/TII Darul Islam/Tentara Islam Indonesia-Darul Islam/Islamic Armed Forces of Indonesia

DKI Daerah Khusus Ibu Kota-Jakarta Metropolitant

FBR Forum Betawi Rempug-Betawi Deliberation Association

FKUB Forum Kerukunan Umat Beragama-Religious Harmony Forum

FORMACI Forum Mahasiswa Ciputat-Student Forum Ciputat

FPI Front Pembela Islam-Islamic Defeated Front

GPI Gerakan Pemuda Islam-Islamic Youth Movement

GPI Gerakan Pemuda Islam-Youth Islamic Movement

Jabodetabek Jakarta Bogor Depok Tangerang Bekasi

KAMMI Kesatuan Aksi Mahasiswa Muslim Indonesia-National Front of Indonesian Muslim Students

KNPI Komite Nasional Pemuda Indonesia-National Committee of Indonesian Youth

LDK Lembaga Da'wah Kampus-Islamic Mission organizations at University level (campus)

MUI Majelis Ulama Indonesia-Indonesian Ulema Council

NII Negara Islam Indonesia-Islamic State of Indonesia

NKRI Negara Kesatuan Republik Indonesia-The Unitary State of Republic of Indonesia

OKP Organisasi Kemasyarakatan Pemuda-Youth Community Organization

PKB Partai Kebangkitan Bangsa-National Awakening Party

PKP JIS Pondok Karya Pembangunan Jakarta Islamic Shool

PKS Partai Keadilan Sejahtera-The Prosperous Justice Party

ROHIS Rohani Islam-Islamic Mission organizations in high school

SMA Sekolah Menengah Atas (High School)

SMK Sekolah Menengah Kejuruan (Vocational High School)

UI Universitas Indonesia

UIN Universitas Islam Negeri

UNJ Universitas Negeri Jakarta

\section{References}

Azca, Muhammad Najib. 2013. Yang Muda Yang Radikal: Refleksi Sosiologis TerhadapFenomena Radikalisme Kaum Muda Muslim di Indonesia Pasca Orde Baru. Maarif 8: 19-20.

Azra, Azyumardi I. 2002. Reposisi Hubungan Agama dan Negara: Merajut Hubungan Antarumat. Jakarta: Kompas. ISBN 9789797090449.

Benedek, Wolfgang. 2010. The Human Security Approach to Terrorism and Organized Crime in Post-Conflict Situations. In Transnational Terrorism, Organized Crime and Peace-Building. Edited by Wolfgang Benedek, Christopher Daase, Vojin Dimitrijević and Petrus van Duyne. London: Palgrave Macmillan.

Benedek, Wolfgang, and Alice Yotopoulos-Marangopoulos, eds. 2004. Anti-Terrorist Measures and Human Rights. Leiden and Boston: Martinus Nijhoff Publishers. ISBN 978-9004140738.

Bowen, John. 1993. Muslims through Discourse. Princeton: Princeton University Press.

Cribb, Robert. 2000. Historical Atlas of Indonesia. Richmond: Curzon Press.

Fitriani, Alif Satria, Pricilia Putri Nirmala Sari, and Rebekha Adriani. 2018. "The Current State of Terrorism in Indonesia: Wulnerable Groups, Works, and Responses" from CSIS Working Paper Series WPSPOL-02/2018. Jakarta: Centre for Strategic and International Studies.

Harsono, Andreas. 2019. Race, Islam and Power: Ethnic and Religious Violence in post-Suharto Indonesia. Clayton: Monash University Press.

Hasan, Noorhaidi. 2007. The Salafi movement in Indonesia; Transnational dynamics and local development. Comparative Studies of South Asia, Africa and the Middle East 27: 83-94. [CrossRef]

Hefner, Robert. 2001. Civil Islam: Islam dan Demokratisasi di Indonesia, in Indonesian translation by the Institute for the Study of the Free Flow of Information (ISAI). Jakarta: ISAI.

Hefner, Robert. 2016. Shari'a Law and Modern Muslim Ethics. Bloomington: Indiana University Press. 
Kolig, Eric. 2005. Radical Islam, Islamic Fervour, and Political Sentiments in Central Java, Indonesia. European Journal of East Asian Studies 4: 55-86. [CrossRef]

Kustana, Tatan. 2017. Islamic terrorism in Indonesia: Addressing Government Strategies and Muslim Population. Jurnal Pertahanan 3: 77-100. [CrossRef]

Moleong, Lexy J. 2006. Metodologi Penelitian Kualitatif. Bandung: PT. RemajaRosdakarya. ISBN 979-514-051-5.

Rane, Halim. 2019. Cogent Religious Instruction: A Response to the Phenomenon of Radical Islamist Terrorism in Australia. Religions 10: 246. [CrossRef]

Situmorang, Abdul W. 2007. Gerakan Sosial. Studi Kasus Beberapa Perlawanan. Yogyakarta: Pustaka Pelajar. ISBN 978-979-1277-85-3.

Suryadinata, Leo. 2018. Islamism and the New Anti-Terrorism Law in Indonesia. Available online: https: //www.iseas.edu.sg/images/pdf/ISEAS_Perspective_2018_39@50.pdf (accessed on 12 June 2019).

Van Bruinessen, Martin. 2013. Ghazwul fikri or Arabisation? Indonesian Muslim responses to globalization. In Dynamics of Southeast Asian Muslims in the Era of Globalization. Edited by Ken Miichi and Omar Farouk. Tokyo: Japan International Cooperation Agency Research Institute, pp. 47-70.

Zakiyah. 2016. The Chronicle of Terrorism and Islamic Militancy in Indonesia. Analisa Journal of Social Science and Religion 1: 19-40. [CrossRef]

(C) 2020 by the authors. Licensee MDPI, Basel, Switzerland. This article is an open access article distributed under the terms and conditions of the Creative Commons Attribution (CC BY) license (http://creativecommons.org/licenses/by/4.0/). 